\title{
THE INFLUENCE OF READING AND WRITING ON THE PREVALENCE OF MYOPIA
}

\section{WPLYW CZYTANIA I PISANIA NA CZESTOŚĆ WYSTĘPOWANIA KRÓTKOWZROCZNOŚCI}

\author{
Katedra i Klinika Okulistyki Pomorskiego Uniwersytetu Medycznego w Szczecinie \\ al. Powstańców Wlkp. 72, 70-111 Szczecin \\ Kierownik: prof. dr hab. n. med. Wojciech Lubiński \\ ${ }^{1}$ Zakład Biochemii Katedry Biochemii i Chemii Medycznej Pomorskiego Uniwersytetu Medycznego w Szczecinie \\ al. Powstańców Wlkp. 72, 70-111 Szczecin \\ Kierownik: prof. dr hab. n. med. Dariusz Chlubek
}

\section{Streszczenie}

Wstęp: W badaniach postanowiono odpowiedzieć na pytanie czy dłuższy czas poświęcany na czytanie i pisanie prowadzi do częstszego występowania krótkowzroczności.

Materiat i metody: Przebadano 70 osób (140 oczu) 17 mężczyzn i 53 kobiety w wieku 18-29 lat (średnia 22,5 $\pm 2,8$ ). U wszystkich badanych osób przeprowadzono ankietę uwzględniającą średni czas w ciągu doby poświęcany na czytanie lub pisanie oraz badanie okulistyczne: ostrość wzroku, badanie przedniego odcinka i dna oka, badanie keratometryczne, autorefraktometryczne, długości osiowej gałki ocznej (za pomocą IOL Master). Wyniki wad refrakcji wyrażano w formie ekwiwalentu sferycznego (SE). Przyjęto, że w przypadku nadwzroczności SE jest większy od +0,5 Dsph, w normowzroczności SE jest większy od -0,5 i mniejszy od +0,5 Dsph. Uznano, że krótkowzroczność występuje wówczas, gdy SE badanego oka jest mniejszy od -0,5 Dsph. W przypadkach krótkowzroczności wysokiej SE jest mniejszy od -8 , krótkowzroczności średniej mieści się w granicach -8 do -4 , krótkowzroczności niskiej jest mniejszy od -0,5, a większy od -4 Dsph. Wyniki badań wprowadzono do elektronicznej bazy danych za pomocą programu Excel, a następnie poddano analizie statystycznej przy użyciu programu Statistica 10. Przyjęto poziom istotności $\mathrm{p}<0,05$.

Wyniki: Stwierdzono, że osoby z krótkowzrocznością niską poświęcały na czytanie i pisanie istotnie więcej czasu niż osoby normowzroczne (5,8 $\pm 2,4$ vs 4,1 $\pm 2,4$ godz./dzień, $\mathrm{p}=0,003)$. Nie zaobserwowano zależności pomiędzy czytaniem i pisaniem a krótkowzrocznością średnią, wysoką i nadwzrocznością ( $\mathrm{p}>0,05)$.

Wniosek: Praca wzrokowa do bliży prowadzi do częstszego występowania krótkowzroczności niskiej.

H a s $\nmid$ a: czytanie - pisanie - krótkowzroczność.

\section{Summary}

Purpose: In this study we decided to answer the question of whether spending more time on reading and writing leads to higher prevalence of myopia.

Material and methods: A total of 70 people (140 eyes) 17 men and 53 women aged 18-29 years (mean $22.5 \pm 2.8$ ) were examined. A questionnaire concerning the amount of time spent each day on reading and writing, as well as ophthalmic examination involving: visual acuity, anterior segment and fundus examination, keratometry, auto-refractometry and axial length of the eyeball measurement (using IOL Master) were carried out in all participants. The refractive errors were described as spherical equivalents (SE). Hyperopia was defined to be SE higher than $+0.5 \mathrm{Dsph}$, and emmetropia to be higher than -0.5 and lower than +0.5 Dsph. Myopia was defined to be with a SE lower than -0.5 Dsph. High myopia was defined as SE lower than -8 , medium myopia in the range between -8 and -4 , and low myopia lower than -0.5 and higher than -4 Dsph. The obtained results were typed into an Excel spreadsheet and analyzed 
statistically using Statistica 10 software. P values of $<0.05$ were considered statistically significant.

Results: It was found that people with low myopia spent statistically more time on reading and writing than participants in the emmetropic group (5.8 \pm 2.4 vs $4.1 \pm 2.4 \mathrm{~h} /$ day, $\mathrm{p}=0.003)$. A relationship between reading and writing and medium and high myopia and hyperopia was not observed $(\mathrm{p}>0.05)$.

Conclusion: Near visual work leads to higher prevalence of low myopia.

K e y w ord s: reading - writing - myopia.

\section{Introduction}

Myopia is a serious health problem throughout the world. Unfortunately, the prevalence of this refractive error is constantly rising.

Over the past 50 years the incidence of myopia has increased significantly. At present, 1.6 billion people throughout the world have myopia. In the USA and in Western Europe this refractive error affects $25 \%$ of people over the age of 40 years. It is believed that 2.5 billion people ( $1 / 3$ of the world population) will have myopia in the year $2020[1,2,3,4,5]$.

Despite myopia being such a serious health problem for modern society, no effective method of treatment has been developed. Only a few methods of management in people with myopia have been devised [1].

Currently, most researchers accept that the rising incidence of myopia can be attributed to intensive near work, especially reading and writing $[1,3,5,6,7,8,9,10]$. However, some question this finding $[11,12,13]$.

Therefore, in this study we decided to answer the question of whether spending more time on reading and writing leads to higher prevalence of myopia.

\section{Material and methods}

A total of 70 people (140 eyes) - 17 men and 53 women aged $18-29$ years (mean $22.5 \pm 2.8$ ) were examined. A questionnaire concerning the amount of time spent each day on reading and writing, as well as ophthalmic examination involving: visual acuity, anterior segment and fundus examination, keratometry, auto-refractometry and axial length of the eyeball measurement (using IOL Master) were carried out in all participants. The refractive errors were described as spherical equivalents (SE). Hyperopia was defined to be SE higher than +0.5 Dsph and emmetropia to be higher than -0.5 and lower than $+0.5 \mathrm{Dsph}$. Myopia was defined to be with a SE lower than -0.5 Dsph. High myopia was defined as SE lower than -8 , medium myopia in the range between -8 and -4 , and low myopia lower than -0.5 and higher than -4 Dsph. The obtained results were typed into an Excel spreadsheet and analyzed statistically using Statistica 10 software. The Mann-Whitney test was used to compare time of reading and writing between groups. $\mathrm{P}$ values of $<0.05$ were considered statistically significant.

\section{Results}

In the performed investigations it was found that people with low myopia spent statistically more time on reading and writing than participants in the emmetropic group (5.8 \pm 2.4 vs $4.1 \pm 2.4 \mathrm{~h} /$ day, $\mathrm{p}=0.003$ ).

A relationship between reading and writing and other refractive errors was not observed when subjects with these refractive errors were compared to the emmetropic group. In the case of hyperopia it was $5.3 \pm 2.2 \mathrm{~h} /$ day $(\mathrm{p}=0.096)$, medium myopia $4.9 \pm 2.6 \mathrm{~h} /$ day $(\mathrm{p}=0.257)$, high myopia $4.1 \pm 2.5 \mathrm{~h} /$ day $(\mathrm{p}=0.714)-$ table 1 .

$\mathrm{T}$ a $\mathrm{b} / \mathrm{l}$ 1. Dependence between reading, writing and refraction of the eye

\begin{tabular}{lccccc}
\multirow{2}{*}{$\begin{array}{c}\text { Refraction } \\
\text { of the eye }\end{array}$} & $\mathrm{n}$ & \multicolumn{4}{c}{ Time of reading and writing (h/day) } \\
\cline { 3 - 6 } Hyperopia & 18 & 5.3 & 2.2 & 0.096 \\
\hline Emmetropia & 34 & 4.1 & 2.4 & - \\
\hline \multirow{2}{*}{\begin{tabular}{l} 
Myopia \\
\cline { 2 - 5 }
\end{tabular}} & low & 60 & 5.8 & 2.4 & 0.003 \\
\cline { 2 - 6 } & medium & 19 & 4.9 & 2.6 & 0.257 \\
\hline
\end{tabular}

* Mann-Whitney test for comparison with emmetropic group

\section{Discussion}

The incidence of myopia depends on genetic and environmental factors. Beyond doubt the most important environmental factor leading to the development of myopia is visual near work such as: reading, writing, and working on a computer. It is believed that during intensive near work the image viewed is focused slightly posterior to the retina, which may induce accommodative spasm, deformation of the image on the retina, and an increase of the axial length of the eyeball $[1,3,4,14]$.

Recently, it has been shown that eyelid pressure on the cornea during reading or visual work on a computer may lead to the development of corneal aberrations. These changes occur more often in myopic eyes than in emmetropic eyes. It has been observed that reading or working on a computer leads to different topographical locations of these corneal aberrations. Reading compared to visual work on a computer tends to induce more corneal aberrations. It is believed that corneal aberrations which develop as a result of reading or visual work on a computer may play an important role in the development of myopia [1].

In numerous publications it has been shown that the worldwide occurrence of myopia has no racial predilection. 
$\mathrm{T}$ a b 1 e 2. Dependence between reading, writing and myopia

\begin{tabular}{llllc}
\multicolumn{1}{c}{ Authors } & Country & $\begin{array}{c}\text { Age } \\
\text { (years) }\end{array}$ & n & $\begin{array}{c}\text { Dependence } \\
\text { between } \\
\text { reading, } \\
\text { writing and } \\
\text { myopia }\end{array}$ \\
\hline Wong et al., 1993 [10] & $\begin{array}{l}\text { Hong } \\
\text { Kong }\end{array}$ & $15-39$ & 408 & + \\
\hline Kinge et al., 2000 [7] & Norway & $20-25$ & 224 & + \\
\hline Saw et al., 2001 [9] & Singapore & $18-23$ & 429 & + \\
\hline Mutti et al., 2002 [8] & USA & $13-14$ & 366 & + \\
\hline Loman et al., 2002 [12] & USA & $21-45$ & 177 & - \\
\hline Saw et al., 2006 [13] & Singapore & $7-9$ & 994 & - \\
\hline Jones et al., 2007 [11] & USA & $7-14$ & 514 & - \\
\hline Czepita et al., 2010 [6] & Poland & $6-18$ & 5865 & + \\
\hline
\end{tabular}

Czepita et al. [6], Kinge et al. [7], Mutti et al. [8], Saw et al. [9] and Wong et al. [10] have all concluded the existence of a relationship between reading and writing and myopia. However, Jones et al. [11], Loman et al. [12] and Saw et al. [13] did not observe such a relationship. This was most likely caused by differences in the intensity of visual near work and the different age of the examined population - table 2.

In our investigations it was found that people with low myopia spent statistically more time on reading and writing than participants in the emmetropic group. This suggests that reading and writing leads to the development of myopia. This is consistent with the results of most studies $[1,3,4,5,6,7,8,9,10]$.

A relationship between reading and writing and medium and high myopia was not observed. This was most likely caused by the fact that medium and high myopia are genetically determined, while the development of low myopia depends on environmental factors such as reading, writing, and working on a computer $[1,3,4,14]$.

\section{Conclusion}

Near visual work leads to higher prevalence of low myopia.

\section{References}

1. Czepita D.: Myopia - incidence, pathogenesis, management and new possibilities of treatment. Russ Ophthalmol J. 2014, 7, 960-101.

2. Czepita D., Żejmo M., Mojsa A.: Prevalence of myopia and hyperopia in a population of Polish schoolchildren. Ophthalmic Physiol Opt. 2007, 27, 60-65.

3. Morgan I.G., Ohno-Matsui K., Saw S.M.: Myopia. Lancet. 2012, 379, 1739-1748.

4. Wojciechowski R.: Nature and nurture: the complex genetics of myopia and refractive error. Clin Genet. 2011, 79, 301-320.

5. Zadnik K., Mutti D.O.: Incidence and distribution of refractive anomalies. In: Borish's clinical refraction. Ed. W.J. Benjamin. Butterworth-Heinemann, St. Louis 2006, 35-55.

6. Czepita D., Mojsa A., Ustianowska M., Czepita M., Lachowicz E.: Reading, writing, working on a computer or watching television, and myopia. Klin Ocz. 2010, 112, 293-295.

7. Kinge B., Midelfart A., Jacobsen G., Rystad J.: The influence of near-work on development of myopia among university students. A three-year longitudinal study among engineering students in Norway. Acta Ophthalmol Scand. 2000, 78, 26-29.

8. Mutti D.O., Mitchell G.L., Moeschberger M.L., Jones L.A. Zadnik K.: Parental myopia, near work, school achievement, and children's refractive error. Invest Ophthalmol Vis Sci. 2002, 43, 3633-3640.

9. Saw S.M., Wu H.M., Seet B., Wong T.Y., Yap E., Chia K.S. et al.: Academic achievement, close up work parameters, and myopia in Singapore military conscripts. Br J Ophthalmol. 2001, 85, 855-860.

10. Wong L., Coggon D., Cruddas C.H., Hwang C.H.: Education, reading, and familial tendency as risk factors for myopia in Hong Kong fishermen. J Epidemiol Community Health. 1993, 47, 50-53.

11. Jones L.A., Sinnott L.T., Mutti D.O., Mitchell G.L., Moeschberger M.L., Zadnik K.: Parental history of myopia, sports and outdoor activities, and future myopia. Invest Ophthalmol Vis Sci. 2007, 48, 3524-3532.

12. Loman J., Quinn G.E., Kamoun L., Ying G.S., Maguire M.G., Hudesman D. et al.: Darkness and near work. Myopia and its progression in third-year law students. Ophthalmology. 2002, 109, 1032-1038.

13. Saw S.M., Shankar A., Tan S.B., Taylor H., Tan D.T.H., Stone R.A. et al.: A cohort study of incident myopia in Singaporean children. Invest Ophthalmol Vis Sci. 2006, 47, 1839-1844.

14. Goss D.A.: Development of ametropias. In: Borish's clinical refraction. Ed. W.J. Benjamin. Butterworth-Heinemann, St. Louis 2006, 56-92. 